\title{
Drug Vehicle Volume
}

National Cancer Institute

\section{Source}

National Cancer Institute. Drug Vehicle Volume. NCI Thesaurus. Code C70963.

A volume of a carrier or inert medium used as a solvent in which a medicinally active agent is formulated and/or administered to the subject. 